\title{
Covid-19: A Challenging Enigma to Global Education
}

\section{OPEN ACCESS}

Manuscript ID:

EDU-2021-09033910

Volume: 9

Issue: 3

Month: June

Year: 2021

P-ISSN: 2320-2653

E-ISSN: 2582-1334

Received: 19.03.2021

Accepted: 04.05.2021

Published: 01.06.2021

Citation:

Kanthimathi, S., and B. William Dharma Raja. "Covid-19: A Challenging Enigma to Global Education." Shanlax International Journal of Education, vol. 9, no. 3, 2021, pp. 221-224.

DOI: https://doi.org/10.34293/ education.v9i3.3910

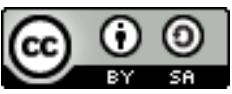

This work is licensed under a Creative Commons Attribution-ShareAlike 4.0 International License

\section{S. Kanthimathi}

Ph.D. Research Scholar in Education

Manonmaniam Sundaranar University, Tirunelveli, Tamil Nadu, India

\section{B. William Dharma Raja}

Dean of Arts, Head, Department of Education

Manonmaniam Sundaranar University, Tirunelveli, Tamil Nadu, India

\section{Abstract}

The Global Education landscape has dramatically changed in the past few months due to the spread of the Corona Virus, otherwise known as COVID-19. The article highlights the pulse of prospective students and Educational Institutions throughout this crisis.

The article explores the findings, including the impact on student's careers, online learning offerings, campus management and a range of other areas. Students worldwide have been dramatically impacted by the spread of the Corona Virus, from travel restrictions to social distancing, isolation measures, quarantines, campus closures and border closures.

Hence, the objective of the study is to assess the impact of Global Education and to determine the various benefits, challenges and reasons on Virtual Education against the challenging enigma.

The COVID-19. Network issues, lack of awareness and lack of training were also stated as a challenging enigma; less attendance and lack of interaction were found to be the significant drawbacks too. Above all, the study also suggested ways to overcome the challenges. "Various studies have been conducted where it appears that different institutions have been adopting and doing well with this new learning environment" (Oblinger and Kidwell, 2000).

Thus the COVID-19 changes have brought a promising future of learning and the accelerated changes in modes of delivering quality education. Global learning can continue to be integrated into classes, curricular and co-curricular activities and programs.

Keywords: COVID-19, Challenges, Education, Environment, Global, Institution

\section{Introduction}

The Pandemic has hit around 211 countries of the world. Different communities are working worldwide to control the situation to limit the spread of the virus. The lockdown has largely affected the lives of students as they no more get to interact on a one-on-one basis with their teachers. At this time of crisis, it becomes challenging to keep Education continuous and unaffected due to this disastrous pandemic. There has to be a system where there is togetherness between the students and teachers without actually being together. In this time of crisis, "Various educational organizations have come together and developed a variety of platforms to participate in Virtual Teaching-learning projects." (Dalton, et al., 2002). Hence the study highlights that "more and more students now have the facilities to progress in their Educational field while being safe in the home premises." (Robinson, 1996; Wojciechowski and Palmer, 2005). Different webinars, online courses have been developed. This has led to a more digital system of teaching as well as learning. Hence, there is a challenging face of Education from traditional classroom teaching to technology-based online teaching. 
Above all, the COVID-19 pandemic has opened the doors of opportunity to get into digital learning (Dhawan, 2020). The environment at home may not be conducive for learning, but Education is mandatory. Online platforms make the students learn compulsorily amidst COVID-19. E-Learning has played a pivotal role, helping the management, teachers, parents and students to adapt to the challenging changes. (Subedi, et al., 2020) It is left to the mindset of the students to learning and teachers also have to find different approaches to teach online. (Doucet, et al., 2020). Moreover, physically challenged students, high achievers, low achievers and the average are benefitted, through few face emotional or psychological problems at home (Petri, 2020). Still, COVID-19 is facing phase 2 challenges. It may lead to lifelong e-learning too. (Murgatrotd, 2020). Sometimes, the teachers may find difficulty in assessing the student's academic performance through online exams. (Sintema, 2020). Due to prolonged lockdown, cancellation or postponement of exams are possible, but students have to face challengingly. (United Nations, 2020)

\section{Review}

Systematic reviews of the effects of school or college closure on influenza outgrow or pandemics suggest that school closures are often low. However, there was substantial evidence that transmission surged again once schools reopened. Going to school is the best public policy tool available to raise skills. While school time can be fun and can raise social skills and social awareness, from an economic point of view, the primary point of being in school is that it increases a child's ability. But can we estimate how much the COVID-19 interruption will affect learning? Not very precisely, as we are in a new world, but we can use other studies to get an order of magnitude. Response to the pandemic within the International Education community has varied from heroic to problematic. Educators, leaders, administrators and education policy workers navigate shifting information, priorities, resources and political and economic concerns. Hence, many challenges and obstacles to provide essential educational services have emerged. Amidst this COVID-19, many universities worldwide provide substantial support to schools, emerging leaders, sharing resources, advice and support as practitioners search for answers and ideas on how to proceed. "Learning program is mandatory as a means of public austerity." (Katzman Blumenstyk, 2020).

Learning never stops. The value of schooling is very important (UNESCO, 2020). Students who are not proficient in a particular subject may be trained using tools and technology through e-learning in this lockdown. (UIS, 2017). Everyone should be aware of the duties and responsibilities in the lockdown and how to overcome the backward situation globally. Hence, education is the only tool. (World Economic Forum, 2019). The right to educate children must be brought as a law even in this pandemic situation as it is the only source for future life. (UNESCO). Hence, the move to online learning becomes a necessity, a great shift from the school environment to the digital classroom. So, this crisis is indeed an opportunity to update the students' practice in academic on the whole. (W. Strielkowski, 2020)

\section{Results of the Statistic Tools}

From the above methodology, the research scholar has given a vivid result through the data collection. The girls were more in numbers when compared to boys. Equal distribution of age was also done to analyze in a better manner. Hence, there was a gradation of age from age 12 to 16 years.

The perception of school-going temperament and lock-down phenomena varied drastically. Since it is the beginning of COVID-19, 74\% of students liked the lockdown education, and the remaining disliked it. Apart from gender, age and likes and dislikes, the students were attracted to the varied tools introduced to them like Audio, PPT, Video and Video conferencing and webinars. There was an increase in the interest in video conferencing and webinars. This shows, students would like to interact well and interaction is part and parcel of today's education.

Hence, Global education during the lockdown is indeed a challenging task for students and accepts it positively.

\section{Methodology}

"There are certain challenges which the online and another mode of teaching and learning throws 
at faculty members as well as the students." (Palloff \& Pratt, 2003). A survey was done recently on the challenging enigma of COVID-19 and Global Education at Graphic Era Hill University, Dehradun, Uttarakhand. Nearly 200 students participated in the study. Based on this, the scholar of this present study too surveyed school students. The questionnaire designed for the students consisted of the student's likes and dislikes on Education, their challenges through lockdown, Online Education, and the future career. The data collected were analyzed for further study by the scholar.

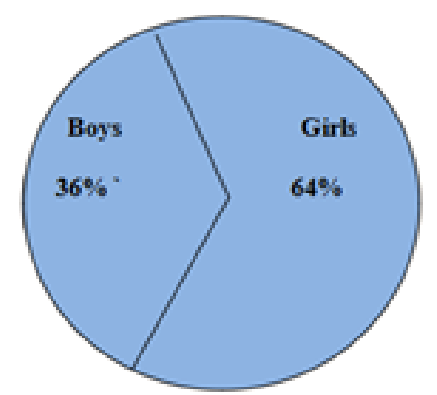

\section{Figure 1: Gender Distribution of the Study}

The questionnaire was answered by boys and girls of varied ages. Most of the students were between 13 years to 16 years.

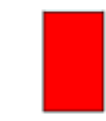

12-13 years

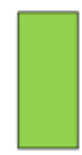

13-14 years

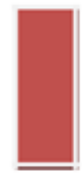

14-15 years

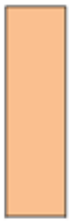

15-16 years
Figure 2: Age Distribution of the Study

\section{Analysis}

An analysis of the study was done. Certain reasons were identified, which could may a lead role for students when it comes to Global Education. Some students stated problems due to lockdown, as they miss co-curricular activities, not meeting friends, language issues and so on when Education is within the four walls. From figures 1 and 2, under the methodology, the survey was taken into consideration.

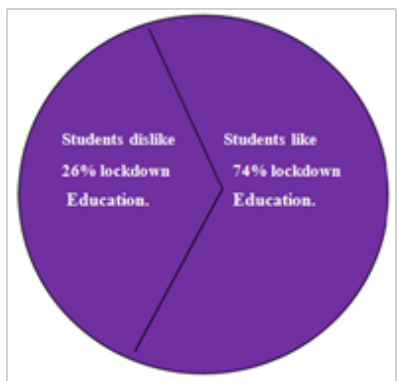

Figure 3

\section{Perception Regarding the Challenges on Global Education}

There are different means available through which Global Education can be effectively carried out. After analyzing the results, the most common source of Global Education mentioned by students was PPTs with audio, followed by videos, webinars and video conferring. These are the challenges ahead for the students.

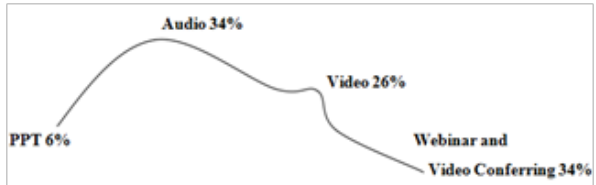

\section{Figure 4: Students Face Challenges Globally}

From the data collected, a good amount of students prefer to accept the challenges on Global Education through varied means amidst COVID-19.

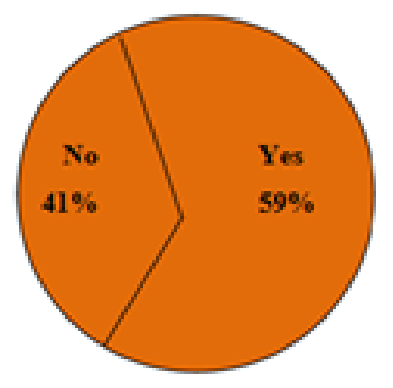

Figure 5

\section{Recommendations and Conclusion}

The present study was thus designed to understand the student's perspective, attitudes and readiness to accept the Global challenging Education. In this time of crisis, various Global Educational Organisations have come together and developed a variety of platforms to participate in varied teaching - learning 
projects. Learning is a continuous process, and amidst the lockdown, the Institutions transformed from classroom teaching \& virtual teaching to keep the learning process on the go.

Hence this study can be carried out in a larger group of students to understand their beliefs and perception about Global Education. At this point, where the entire world is fighting to win over Corona, it is very important to keep an effective Education process continuous, which the students enjoy and gain. Such a study would help the Education Ministry develop certain rules and guidelines wherein certain online activity sessions can be made compulsory along with regular lecture sessions.

To conclude, Global Education during COVID-19 is a big challenge to the student and teaching fraternity. Indeed, "A student can study anywhere and at any time he wants with a few exceptions." (Carnevale, 2000; Dutton et al, 2002).

\section{References}

Carnevale, Dan. "Study Assesses What Participants Look for in High-Quality Online Courses." Chronicle of Higher Education, 2000.

Dhawan, Shivangi. "Online Learning: A Panacea in the Time of COVID-19 Crises." Journal of Educational Technology Systems, vol. 49, no. 1, 2020, pp. 5-22.

Doucet, Armand, et al. Thinking about Pedagogy in an Unfolding Pandemic: An Independent Report on Approaches to Distance Learning during COVID19 School Closures. Work of Education International and UNESCO, 2020.

Dutton, John, et al. "How do Online Students Differ from Lecture Students?" JALN, vol. 6, no. 1, 2002, pp. 1-20.

Harper, Kimberly C., et al. "Distance Learning, Virtual Classrooms and Teaching Pedagogy in the Internet Environment." Technology in Society, vol. 26, no. 4, 2004, pp. 585-598.

Inclusion and Education: All Means All. UNESCO, 2020.

Mansour, Bassou E., and Davison M. Mupinga. "Students Positive and Negative Experiences in Hybrid and Online Classes." College Student Journal, vol. 41, no. 1, 2007, pp. 242-248.

More Than One-Half of Children and Adolescents are not Learning Worldwide. UNESCO Institute for Statistics, 2017.

Murgatrotd, S. COVID-19 and Online Learning. 2020.

Oblinger, Diana, and Jill Kidwell. "Distance Learning: Are We Being Realistic?" Educause Review, 2000, pp. 30-34.

Petrie, Chris, et al. Spotlight: Quality Education for all during COVID-19 Crisis. Hundred Research Report \#011, 2020.

Policy Brief: Education during COVID-19 and beyond. United Nations, 2020.

Robinson, Debra A., et al. "Orientation Programs: A Foundation for Student Learning and Success." New Directions for Student Services, no. 75, 1996, pp. 55-68.

Sintema, Edgar John. "Effect COVID -19 on the Performance of Grade 12 Students: Implications for STEM Education." EURASIA Journal of Mathematics, Science and Technology Education, vol. 16, no. 7, 2020.

Subedi, Suraksha, et al. "Impact of E-learning during COIVD-19 Pandemic among Nursing Students and Teachers of Nepal." International Journal of Science and Healthcare Research, vol. 5, no. 3, 2020, pp. 68-76.

\section{Author Details}

S. Kanthimathi, Ph. D. Research Scholar in Education, Manonmaniam Sundaranar University, Tirunelveli, Tamil Nadu, India

Prof. B. William Dharma Raja, Dean of Arts, Head, Department of Education, Manonmaniam Sundaranar University, Tirunelveli, Tamil Nadu, India 